\title{
Short Shrift in the Schwarzwald
}

\author{
I \\ The world revolves around my viola.
}

Tennyson

ALL MORNING, I remember, the weather had been sullen, ambiguous; and I hear in my mind again over the wall from the garden the cries of the peacocks, raucous among the pines. It was late in a season unseasonably warm, the year of the Seven Weeks' War.

"There is something intrinsically unsatisfactory," said the Count as he attacked-with the resigned look that an ancestor might have worn in mid-exercise of his droit du seigneur - the blushing skin of a Josephine de Malines, "about these late-maturing beauties." His fruit-knife slid smoothly down its small ovoid flank, exposing beneath a sundappled strip of dermis a width of flesh. "Nevertheless," he continued, "noblesse oblige." With gingerly tines he pecked out a bite-sized piece. "Not bad," he went on through the napkin wiping his lips; and turning to me, "Won't you have a macaroon?" he said. "Tita, pass Hugo the macaroons."

I may have loved her most just then, as her round white foreshortened forearm came blooming out of its yellow silk dressing gown sleeve, languid palm curving to hold up a scalloped blue-patterned plate, ringless fingers gripping, tensed. I stared at that childishly graceful proffering thumb, as appealing as pinkly unplucked fruit, and heard unmistakeable mind's ear music: a song from the skin-touched edge of a plateful of macaroons, saying that somewhere remote, on hard-packed sands, walked naked divinity, risen once more from the depth of a foamy sea. Cold sweat broke out on my upper lip.

When I looked in her face to refuse, however, I saw nothing flirtatious, no inkling on her part of an understanding of men, nothing but an inscrutable smile, whose full-blooded lips and small white teeth seem to me now to stand as boldly indifferent to my remembered lust as the high gleaming prow of a fancy taut-pooped new little boat to the sluggish batter and flux of some tired and greyly garbage-laden wave.

A deerhound under the lunch-table groaned.

She was sixteen, my godfather sixty-six. They sat on the terrace in 
dressing gowns and I pretended not to observe that their feet, hers so tenderly arched and white in their insteps, the Count's so clawlike, moved in and out beneath the oblivious marble of our lunch-table-top and played together like wanton puppies.

She had brought a couple of deerhounds with her to Baden-Baden, gifts, I learned, of the Count.

He called her Tita. Her name was Maria Livada and she had come with him to live in his house, travelling as his niece, arriving with her dogs and baggage only three days before I did. She was part of the Count's entourage, a small piece of his habit of life, and so, I suppose, in a different way, was I.

At this point, for the sake of form, I should intrude, however clumsily, and say something about myself. At the time of the events I am describing here I was a little more than thirty-five and am considerably older now. To my long-dead parents I owe such wholly impersonal distinctions as money and its concomitants, all the things, that is, including a great deal of happiness, that some money can buy. Outside of a more or less tolerable state of physical preservation, I lay no claim to any kind of personal distinction, having managed to evade all employment of any talent whatever I once might have thought I possessed. My life has not been uneventful, however, and I have lived in several cities of the world, dividing my recent years among three or four of the best, though it was in Antwerp, never one of the best, that a year or so ago I found myself suddenly afflicted. What came over me as I stood waiting between trains was an attack of almost total recall of certain things in my life, which I discovered could only be purged or dispelled by writing and publication, pseudonymous, of course. The result at that time was a sort of novella called "The Dämmerung of the Budgerigar," which has begun, I am told, to receive puzzled notice in several literary reviews.

But I am puzzled myself as to both the source and meaning of this visitation and why it compelled me to do something so unlikely as to sit down at a desk and scribble. I am not a writer; and in any case I grew up, like most members of my class, with five languages beating around my head, half-instructed and semi-literate in them all, so that all are equally foreign tongues, though English is the one that comes to me most readily.

Imagine then my reaction to a second such visitation, this time in the railway station at Milan, which brought me in a single flash of recol- 
lected images more or less what I am writing now, with the difference this time that what I write cannot be published until after I am dead. From whosoever may chance to read the following autobiographiconarrative remarks, I beg a double favor: to understand the compulsions behind what he reads and having done so disregard them, treating everything that flows here beneath his eye and mind with rational detachment.

For the rest, aside from the fact that my name in this text is Hugo, the reader should perhaps know that at the age of thirty-five-odd I stood at medium height, was stocky, snub-nosed, and had what I think I shall describe as very pleasant features.

Count Julius had summoned me in urgent language there to BadenBaden, as his long-standing special relationship with my family allowed him to do, to spend a few days with him and discuss what he called some important affairs. He had particularly instructed me not to bring my valet, since that would be an "unnecessary expense." I had, of course, foolishly jumped to the hopeful conclusion that the old man's health was bad and that he must be planning that final disposition of his estate in which I, his only godson and the closest thing he had to a living male heir, would figure with natural prominence. I therefore answered his summons with considerable alacrity, for though fond of the Count, in a curious sort of way, as I had been fond, for example of the aging and foul-mouthed parrot whose white-spotted perch had at one time stood in a corner of my poor dead mother's boudoir, I was young then, more adventurous, and poorer than I am now. And besides not having been able to pay my respects to the Count for a year and a half, I had never been before to Baden-Baden.

I had never been to Baden-Baden before. According to his usual custom, Count Julius did not meet me personally when I arrived. It was a duty he preferred to leave to servants, especially in the dead of night. Two loutish footmen therefore saluted me at the station, installed me in a landaulet, and then drove me out of the city into the dark pastmidnight countryside. The gateposts of the estate were invisible as we passed between them, but the crunch of gravel under the wheels told me that we had entered the grounds. We drove on further for a few more minutes, then drew to a halt before a miniature house apparently some distance from the château itself, set in what looked in the carriagelights to be a toylike garden of dwarf pines. This, I was told by the two 
footmen, whom I christened Hans and Fritz, was the Häuschen, a sort of garconnière, and they assured me on behalf of the Count, as they carried in my baggage, dusted off their hands and bowed their way back out into the night, that I was most welcome, but that the château was too small to support "another guest." Here, however, everything was laid out for me; I should make myself comfortable as possible, and His Excellency would appear sometime in the following afternoon. In the meantime I was to sleep late and take breakfast and lunch by myself in my own little house.

Everything, which, in so small a place, did not seem to amount to much, had indeed been laid out for me. I smoked a cigar, helped myself to a brandy, and went to bed, a little annoyed at having been tricked into doing without not only the luxuries I might have expected from a man as rich as my godfather was supposed to be, but also certain services to which I was accustomed.

That night I had an extraordinary dream, a dream from which I awoke, as one sometimes does from such visitations of the self upon the self, with the perfect conviction that somehow the secret of what is called life had been completely revealed to me.

I dreamt that it was evening. I was in a room in a house in the suburbs of the capital city of some semi-tropical country. Native maidservants in heavy black dresses and brilliant scarves were lighting the lamps; and I was talking easily at a small round table with two or three nonentities distinguishable only by sex, one of whom, big-bellied, apparently gravid, and blonde, might well have been a cousin, sister, or wife. On the table were a dark blue feather, a lemon with one slice removed, and a white porcelain dish full of water.

A door opened and a hatless man entered, followed by four or five others. The face of this leader was exactly the sort that one could encounter anywhere, a little fleshy, brownish pink in its hue, vaguely well-intentioned in its expression. The other men, however, seemed to embody, though few in number, every physical type to be found in Europe and to exude an indefinable quality of destructiveness. I knew immediately, of course, that they were Secret Police. Just whose perhaps I was not sure, nor did they carry any identifying marks, but I have had enough encounters with secret police even in my relatively inoffensive life to be able to recognize precisely the sensations that in such encounters one inevitably feels; and it was by these feelings that I knew them.

Such feelings are not pleasant. One senses oneself not so much humili- 
ated or degraded as turned suddenly into dirt itself, totally removed from a context where even humiliation and degradation might continue to have any discernible meaning, and thrown headlong into the charnel pit or heap of dung where, very clearly, one really has always belonged. Having lost subjective moral control of one's life, one is dead, of course, in any sense that matters. And since the sole difference between dreams and life is merely that dreams generally exaggerate the living fact that the people and things we meet are either subjective or they are nothing, I momentarily died in my dream of the Secret Police, before my dream-self had even the thought of death.

Worse than anarchists, secret police have no respect for social order. They dragged us into the garden. In normal life I would have been outraged. Being dead, however, my only concern was the order of precedence we would be officially murdered in: it piqued me no end to believe that I would be officially killed in the midst of the others instead of separately, either first or last. It was on this issue, therefore, that inward protest began, evolving from resignation into a desire to live, if only to re-establish subjective moral control. For this reason, curiously enough, I began to cast my mind back-something that in the limited temporal sphere of dreams is not so easy to do-searching for some possible crime of which I might have been guilty. I should have known, and indeed did really know, that guilt or innocence simply did not enter the current account at all, as the laughter and ribald behavior of the police themselves were clearly telling me.

The laughter of them all, that is, except the leader. He seemed unlike the others, serious and intent. He seemed to represent, in fact, a tenuous link with a world of rationality. I recognized, of course, that this feeling in me might be merely the result on his part of a long-practised polished professional pose. Nevertheless I felt him at once to be both totally other than myself, an autonomous object-and therefore incapable of either giving or receiving anything remotely allied with the sympathy such a pose might be designed to elicit — and to be also somehow at least a part with myself of the world to which I had a few seconds before belonged. I felt that despite the fact that I was about to be murdered for some reason I did not know, I must, in my new-found baseness, trust this man, must play a rôle for him in a play which to him was no play at all but some more solemn game, whose ramifications I could not begin to suspect. I felt myself pretending therefore to be much more stupid than is my wont, my trust of him taking the form of a low trapped- 
animal cunning, the form of providing him with an excuse to see me as less dangerous to whatever indistinct cause he defended than I myself, could I understand anything, might understand myself to be, the form of appealing to his presumed experience, that is, with the genuine criminal type. Only by deliberately deceiving him thus could I hope to win control and regain my life.

In the garden he proceeded to subject his prisoners to what appeared to be a test, first one of the female nonentities, then one of the male ones, then another female. One by one they were required to stand at the precipitous edge of a terrace, their backs to him and to the rest of us, holding a black rag doll the size of a full-grown midget. As each of them stood awkwardly at the edge there was a flash of magnesium flare and the pose was apparently registered on a photographic plate.

My turn came. No sooner had I taken the doll in my hands and struck the required pose than the leader muttered something about the proceedings being utterly useless.

In the midst of death, I felt slightly amused: we had put the Police to trouble, making them carry out this ridiculous test before they could kill us. We could take a little comfort in the fact that for a few minutes we had made our persecutors minimally uncomfortable.

I was still standing, looking over the balustrade down the precipice and smiling to myself, when the pregnant blonde, who sat now on a stool next to the balustrade, said, "Look! They're making love!" I turned around. The secret policemen, all of them fully clothed (dark suits), were methodically copulating with the maids also fully clothed (black dresses and shawls) who stood with their legs spread, backs leaning against a lighted wall of the house.

Within a few seconds they had finished. Their leader, who had remained by my side looking on, turned and slowly walked away down the steep gravelled path through the garden to the lights near that gate on the street where I knew now his carriage stood. His minions had been appeased. My ordeal and that of the others, such as it was, was over. He did not apologize, however, and when he asked about my physical health he put the question with such a general tone that he might have been some medical friend or acquaintance, not the author of a late upset that could well have finished an older man, of the age, say, of the Count. He was separating himself from the duties he carried out, making a claim, in effect, for my consideration of him not as the grotesque mechanism of the fears in a political regime, but as a human being. I said that my health was, as it is even now, by and large, excellent. 
"And your mental health?" he added, in the same elaborately indifferent voice.

I was not quite sure what to say. It seemed to me that if I told him how good it seemed at that moment as I accompanied him to the conveyance by which he would leave me, as I performed from habitual politesse an action so utterly congenial, he would interpret his erstwhile presence as having been not quite terrifying enough. I did not wholly believe in this vague mandorla of humanity. Therefore I hesitated; and he appeared to read this calculated hesitation at once as a doubtful testimonial to terror, to his effectiveness in his métier, and as an accusation of his having abused my own so obvious innocence. "You should try some medicine," he suggested and said good-bye. With those words, so perfectly what he should have said in my plan for him if I had had a conscious plan, he became at once my creature.

I awoke in the dark still feeling triumphant, arose by the night-light, opened my cigar-case, picked out, trimmed, and smoked a cigar. With the first puff of smoke came the recognition that I had been given the rarest insight into the human condition and more particularly of my relationship with the world: everyone we know is the Secret Police, to whom we stand in some relation of obscure mutual guilt, defilement, and deception. With that thought enunciated in my mind and almost aloud, I went back to bed quite happy and awoke very late the next morning, a little after noon.

By daylight I could see that the little house's pseudo-rustic charms would undoubtedly exhaust themselves even sooner than I had thought. Outside, however, the grounds, which stretched in every direction, looked rather promising. The carriage lights as we had come up in the dark had failed to show me the gateposts or even the shape of a lodge, nothing but black foliage on either side of the drive, the garden of dwarf pines, and the door of my little abode. After a late breakfast, therefore, strolling out with a stick in hand and another cigar, in aid of digesting a trout, I resolved to do some exploring - the familiar footmen, Hans and Fritz, having wordlessly brought my meal from somewhere, served it, and tidied up, had silently disappeared-to see the rest of the estate, to try to find the château and perhaps my host.

Somehow I gradually lost track of time and space. It was pleasant and moist underfoot. I walked and walked until I seemed to have wandered rather further than I had intended away from the little house, but only as I turned around, in something not yet approaching even mild dismay, did I discover that I did not know how to get back. 
I went this way and that, looking for signs, but every path I took seemed to resolve itself into a thicket. A little desperate, I began to hope for the appearance of a forester or gamekeeper to give me directions. But no one came and I could not even find traces that might show me that someone had recently used any of the paths before.

It did not take long for perturbation to lead to action; and soon I was hacking my way with my stick through viciously indifferent underbrush, sweating at every pore, cursing the Count and cursing myself for not having made enquiries before the servants had gone. I knew I was lost in the vastness of the park, well out of sight of the garconnière, the château, or any familiar mark; and at length, as the afternoon light began to fail, no doubt influenced by my dream of the previous night, I fell prey to growing trepidation. I even surmised that the Count had lured me here, deserted me, withdrawn his servants and left me in the woods to die. I started to shout and got no reply but echoes. No one came.

My unwieldy suspicions, which turned first to imagining a conspiracy, became transformed into total panic; a thousand fearful messages flicked through my brain. By now I was physically and mentally overalert, starting in desperation at every sound. I was in this state, just half-stumbling out of the depths of a ferny dingle, when suddenly the air all around seemed to come alive with the sound of crackling twigs.

I stopped. My ears caught the heavy pant of a hunting beast, whose breath I could almost feel. I crouched, and, surrounded by blinding ferns and foliage, on hands and knees, scrambled irrationally, frantically upward, feeling myself like an animal trapped in an inescapable beat, a guilty Actaeon, the crackling noises all around me, the panting breath like a damp spot on the back of my neck. And when from far too close came the noise of baying hounds, I felt my hair stand on end.

Quite all at once I was free. The ferns and foliage fell away and I found myself standing on the edge of a clearing looking slightly ahead and upward at a spinney of young beeches and red-berried rowans that bristled out of a hillocky swell of open sward. Through the green shadowed grass and the leaves ran a couple of deerhounds, belling, one black, one white, in passage, pursuing nothing.

Intensely but vaguely relieved, I walked to the top of the swell and through the trees, which bent their svelte white trunks to either side, then, descending, found myself in front of an intricate open gate in a high pleached hedge. I stepped through the gate.

There in an alley, paved with round stones and overhung with older 
trees, leading directly to the white-pilastered château, whose staggered red-roan-colored roofs I could see, rising out of a nest of dark-haired pines to culminate in a gilt glandiform-turreted tower, I encountered them both, standing quite still, only a few feet away, facing me.

In the year and a half since I had last seen him Count Julius had grown considerably more stooped and old. Dressed in a black walking suit, smiling, he did not seem surprised to see me at such close quarters, but leaned avidly forward over his gold-knobbed stick.

What caught my attention most, however, even at that moment was nothing about himself, but the mute radiance of the girl who stood beside him.

The Count hopped toward me as I approached, embraced me, then quietly introduced me to Tita. I kissed her hand and as I did so a levin-light instinct told me two things: that Count Julius' health was better in at least one important respect than I had supposed; and that I myself had been tapped by a destiny out of a new and utterly different direction from any, ever before.

Strangely enough (to inject another autobiographical note), though it was to strike me later that I had known all too little about my godfather himself, I had always known who his mistresses were, even when I was a child and he had not been so old. Unlike many men in his position, he lived with them openly, one by one or in groups, and their flexible list could serve as a virtual history of my youth. Though he never brought them, of course, to call at my mother's house, Leblanc, La Schneider, Hassé, La Gioja, the proto-Comtesse d'Amboise, Bellanger, Montaland, la Cook, those priestesses of the Paphian rite, who stuffed me with sweets and allowed me with hot sticky hands to pet their fluffy little lapdogs (always named something like Long, Yin, Am, Yo, Ni, or Yang, depending on sex), were the pampering paranymphs gracing my prepubescence, my playmates at Halma and whist. As I grew to the age, after my father died, when I called at the Count's on my own and not merely because it sometimes suited my mother to have me away from her, they taught me older, more original games, many of them in his absence, neglecting, I fear, to tell the Count that he was paying for such tuition. By that time, of course, since his taste was excellent, fickle, and never repeated itself-"I'm prone," he used to say, "to switches"his Vestal suite had expanded into a house of many mansions, of which I naturally remember, as dating from my fifteenth and sixteenth years, four in particular. 
Jeanne de Pougy: a lithe little Jewess, barely less of a child than I, the smooth hardness of whose small haunches would later be worth millions pawned in the hope of delirious intensity. Open-handed in the extreme to me, she died not long ago in a dirt-floored hovel littered with diamonds, stingy and rich.

Lorraine de Mohun: a statuesque Greek, the Corinthian mass of whose hair either billowed upward, red-gold weight piling endless on red-gold weight as she dressed for a drive in the Bois, or tumbled downward, drowning me in diaphanous down-dragging spume as she undressed for bed. One rainy day she played Lady Godiva for me on a rocking horse strangely relict in the old man's attic, whipping its gay painted crupper just as happily then as many years later-the height of her career-she did with such gusto upstairs at Maxim's the shaggy buttocks of more than one colossal Russian Grand Duke.

Louise de Raspail: a Negress the breadth of whose brown Baudelairean bosom quaked with anomalous elfin laughter, a huge black bon-bon filled with the liquor of life. Twenty years later, elephantine, raucous, bald as an eightball under a bronze-colored wig, she drank herself to death.

And finally Ghislaine de Lorris: a dainty Chinese, the delicate depth of whose tawny navel, glistening with perfume and sweat, reflected, like the cunning curve of a golden goblet, twenty centuries spent in the meditated absorption of sensuous lore.

It was with this last that gratuitous games of gherkin-and-merkin came to their premature end, for one day the Count walked into his own house at an unexpected hour and caught the two of us octopod on the thick-piled Chinese carpet in his dining salon, rapt in a puzzle that would have made Gordius proud and just achieving a frenzied solution. He coughed. We slowly unravelled. He said something in what I took to be Chinese, Ghislaine giggled, and he turned and left, walking out of the room without bothering to close the door.

Thenceforward, to my initial consternation, he clearly saw me with new respect. A few words with my mother persuaded her to put my education on a different basis and within a matter of days I found myself packed up and sent abroad, with little money and fewer blessings, to improve my English at the house of the Reverend Mr. Yfor Richardson, a doddering former clergyman of the Anglican Church, who kept a large cramming establishment in Great Dickham, a squalid village near Oxford. 
Because of its damp setting, high rates of bastardy and illiteracy, and abundance of unnecessary filth, Great Dickham was accounted by the British as especially picturesque: and for perhaps a day, for the first time in my life, I was bewildered and quite unhappy. Old Richardson's declared régime seemed designed to carry out the Count's revenge with a vengeance, by stifling every conceivable appetite. Drooling his way through morning, mid-day, and evening prayers, the old fool's every word was an admonition to curb the flesh, to follow his own example as well as that of our Protestant Lord and Savior, models, we were constantly reminded, of very nearly equivalent stature, though if a Crucifixion were to be awarded for truly overweening asceticism and humility, we were left in no doubt as to who should really be tops. With old Richardson's "counsel and disciplined approach," an approach consisting of frequent threats that he was too spineless and befuddled to carry out, we were expected to learn, like our Master, not only how to cringe and pray but also how to take positive pleasure in dirt, deprivation, and English cooking, while looking forward, of course, to the ultimate joys of senility and impotence.

Needless to say, I rejected both the models and all the farcical exhortation, and a struggle ensued in which I had at first no allies, although there were five of us unfortunates. The names of the others can be of no interest here, but two of them have since been hanged, one of them almost certainly with justice, a third is now in prison for petty fraud, and the fourth approached me not long ago in a lesser London street, recognized me, spun a long tale involving chronic spells of lunacy, and begged for a shilling to buy himself a bed and some drink. These four were all docile obedient pupils, while I was the obstreperous alien, apparently destined from the outset to be alone and friendless in my revolt.

On my second or third day at Great Dickham (the reader will now have an idea of the context) I laid hands on Alice, old Richardson's fourteen-year-old chambermaid, a bit walleyed and bucktoothed, to be sure, but still something of carnality in what promised otherwise to be a desert waste. I had not reckoned, however, on the imbecile results of three centuries of village incest and the girl emitted a penny-whistle shriek that brought the rest of the household running: the cook, Jarvis the butler (an ancient wreck almost indistinguishable in half-lights from his master), a dram-sized footman and an even more wizened scullery lad, all agape, followed in carpet slippers by old Richardson himself. 
When sense was finally made of Alice's hooting, I was peremptorily consigned to the coachman, a huge red-faced Scot named John, for what old Richardson, hardly capable of lifting a soupspoon himself unaided, delighted in terming "stern measures." The coachman was summoned, took me by the collar, and led me out, with a grin, towards the stables.

Once there, of course, the atmosphere changed. I had a few shillings, John produced a bottle of good Scots whisky, a couple of Count Julius' spicier stories broke the ice, and by midnight we were roaring. John's experiences seemed to embrace half the animal kingdom, including the chambermaid I had attempted ("Yer nannies buck," I remember him shouting as he reeled among his horses' rumps, "but yer ewes are verra douce!"), and proved more instructive than anything I had encountered for days. We kept the household awake all night. In the morning old Richardson acknowledged his failure by sending Alice away and attempting to reprimand John, whom he did not dare to dismiss, by ordering him to report for evening prayers and forego drink for a week. As for myself, nothing more could be said, and the harshest punishment thereafter amounted to what I would consent to without undue violence, usually some form of mild imprisonment (as will be seen below), which I would accept at Richardson's plea, for the sake of a few hours' privacy. And even this measure did not amount to much of a change in the daily régime, since the gate in the eight-foot garden-wall around old Richardson's house was kept locked even by day, while the front and back doors were locked, in addition, at night, when we were all shut up in the large attic room that had been roughly outfitted as our dormitory, and the door was barred.

When I protested early in my second week against this last arrangement as condemning us all, in case of fire, to perish like rats in a trap, the old fool supplied us with a rope, which was fastened to a stout iron hook by a window at the gable-end. The first night after the rope was installed I made use of it, scrambling out the window shortly before midnight, chuckling to myself, as I clambered all the way down, at the old man's gullibility, only to discover some twelve feet short of the ground that I had not likewise reckoned with his miserliness, for it was there that the rope came to a frazzled end. Driven by my own needs and having little choice, I dropped to the ground, slightly spraining an ankle, and went limping in the dark to the stable, where I woke John and made him find me a ladder. For a small sum, which he would split with $\mathrm{MacNab}$, the gardener, to defray the expenses of their next Saturday 
night binge ("Mac kens naething in the worruld," John used to say, "but the bousing can and a cozy quim"), he agreed to see that the ladder would be removed at dawn, before old Richardson took his morning prowl round the garden. Having made this happy arrangement, I climbed over the wall, taking the ladder with me, hid it in a hedgerow, and made my way down the pitchdarkness of a country lane toward the nearest speck of light.

If I had had enough cash, I would have bolted all the way back to Paris. As things stood, though, I feared I would have hardly enough money to hold on to my self-respect when I arrived at wherever it was I was going.

The speck of light grew larger and I began to hear sounds of merriment. Someone was playing a piano and male and female voices were singing. I stumbled up to a door and knocked. After a moment it opened. Imagine my joy when I found myself in the warm glow of an improvised rustic brothel, crowded with drunken undergraduates, who belonged, as things turned out, to the most sybaritic club at Oxford. They proved generous, free-spirited, and open-handed, so much so that before the evening was over I had become a sort of mascot, completely giving up my plans to flee to Paris. Their number included many a noble name and many who have since become famous; and over the next three or four nights they introduced me to every crude pleasure the place could afford. Meanwhile I made my arrangement with John a standing one and could come and go over Richardson's wall without much trouble, if not as yet as I pleased.

It was at this juncture, near the end of my second week, that I found myself locked up one afternoon in the old fool's closet, for the alleged high crime of an allegedly low remark about his so-called cook, a hairy hermaphrodite named Charlotte, whose culinary magic seemed able to transform even the most varied and promising raw ingredients into the same daily cold grey stew. What I'd said, in fact, had shown considerably more taste than the creature's cooking: confronted with an Englsh "pudding" that went by the unhappy name of "Spotted Dog," I noted aloud that the English word pudding could only be derived from the Latin pudendum, observed that Richardson's cook must have applied the etymology literally, and to confirm this hypothesis plucked a grey hair or two off the substance in the dish in front of me. Jarvis the butler turned red-faced and staggered out of the room. There was a long silence while everyone stared at his dessert-plate. Then an explosion came from 
the kitchen. Charlotte burst in with a carving knife, shrieking "Dost mock me, Master Hugo, dost mock me?" and I believe that when Richardson intervened to have me locked away, he may have felt that he was possibly saving my life.

In any case, the closet was not so unpleasant. There was room to sit and even lie down and doing so I discovered a small niche at the back, behind a pile of clothing, containing a few old books. Curious, I pulled them out. I had a box of lucifers with me. Selecting one of the books, I struck a light and looked at the title, only to find an old friend, for it was none other than a copy of Miss Whipsnade's Finishing School, which had been one of the minor classics in Count Julius' collection. It was such another collection, I was instantly sure, that I had unearthered here: and striking other matches I rapidly made certain. Here indeed were The $C^{* *}{ }_{t-L o v e r ' s}$ Guide to London Night-Life (with passages underlined, showing a serious study of the subject), The Enormous Ear of Ezz-Eddine: $A$ Tale of Oriental Passion (with illustrations), The Vicemaster's Vademecum (annotated in Richardson's own hand), and a host of other similar works, not excluding the inevitable Fanny Hill, all of them bearing marks of close perusal and one or two of them suspicious stains, in addition, among the interior leaves. Just as I was cursing for not having had the foresight to supply myself with a candle, moreover, I found one, quite fresh, in a corner, and for the next hour or so spent my time in very pleasant company.

When they let me out, I kept one of the smaller items with me; and later, after evening prayers, I left it in Richardson's favorite armchair, where the servants were sure to find it.

The following afternoon I was rewarded by an interview with the old fool himself; and we soon reached an understanding. He surrendered keys to the house and the garden gate, on condition that I revealed nothing to my godfather, who was after all paying handsomely, as always, for my tuition, and I could come and go as I pleased.

The remainder of my stay at Great Dickham was, in fact, quite happy. The old man soon evolved the habit of sitting up waiting for me to return from my escapades in order to question me about them, sharing in them vicariously and becoming more and more engrossed in them as, thanks to the generosity of my undergraduate friends, I was enabled to wander further and further afield. "You wouldn't fool an old man?" he would say, his rheumy eyes bright with impotent reminiscence. On my assurances that everything had happened just as I'd described, his jaw 
would drop, his false teeth would clack together, and he would laugh with all he could muster, a dry wheeze that went on for several seconds, until the moisture running out at the corners of his mouth dripped from the end of his beard to his clerical dickey. Eventually he even lent me money.

Thus on my seventeenth birthday it was practically under old Richardson's approving eye, while his other pupils were abusing themselves in the potting-shed or the coal-hole, that I was sharing the favors, as we named it, of a well known London actress with the old Duke of Mand his son, the Marquess of $\mathrm{V}$ -.${ }^{1}$

I think my godfather may have suspected something even then, as I stood looking at Tita that very first time, for this girl in the alley of trees was like none of the others, the somewhat overblown lilies, some of whom I have described, ${ }^{2}$ who had filled my salad days, so heavily gilt, so utterly uncontent to blush unseen, and so fundamentally indistinguishable-I speak now purely metaphysically-from common whores. Do not suppose that I, like so many an idiot rake as described in stories, was dazzled by the appearance of virtue. It is true that every woman I had met till then had borne the impress of every man she had knownfor which one is always grateful at first and only later resentful-but it is also true that no matter what I had learned of love from them, when we met on that road in the park I felt, at thirty-five years, as waterykneed as an adolescent, flushing as my lips touched the back of her hand, while the consciousness came over me in a wave that these petalled fingers had undammed a force in myself, a force that I knew but had never had time to experience fully before, and set it agush; that the sensual fury that only belongs to earliest youth and never merely to us, was welling anew, to be spent or misspent again, and only in her.

She murmured the accustomed clichés and turned away to let me talk more particularly to the Count, to whom I hardly paid any attention. My eyes never left her, the profiled curve of her spine in the tighttailored dress, her derrière's jut, her clustered breasts, the lashes fringing

1 Editor's note: The remainder of this section of Baden-Baden, suppressed in 1893, at the publication of its first half, under the name Short Shrift in the Schwarzwald, details young Hugo's liaison with the actress and a few of his other amorous adventures, particularly those that led to his consultation with Professor Brownlow and his subsequent resort to the prosthetic skills of Hans Kastorp, the master renowned equally for surgery and goldsmithing in the cities of Prague and Copenhagen. This passage will be restored in full in the Taj Lam Waw Dal edition forthcoming.

2 Editor's note: See also the passage referred to above. 
a double and dangerous-tinder and glittering gems-Pandoran box. As she and the Count said good-bye and passed, my ears pricked up for the sound on the stones of her small heels' click and for the secret hiss, in the rustle of skirts, of the hose on fricative thighs.

They moved on down the alley of trees and left me behind. In the growing distance between us my turbulent thoughts ebbed with her, leaving me feeling utterly empty, deserted, bereft. Like a man marooned, my mind began running back and forth over the whole vacant beach of my soul as she faded out of sight, in desperate search for a thought, for a form, for some sort of durable surface on which to repose, for lack of her skin and flesh, my suddenly reanimated ideal of lust. I felt I could hardly breathe, as if I would starve or drown. What could she have meant to me, this girl, that to see and to lose her thus should so jettison my reason, so devastate and lay waste my mind?

If I found an answer and came to rest, it was at last in her passionate heart-shaped face's bright surfaces, sloe-eyed, gipsy, dimpled and pink as they curved to meet the coal-black caress of curling coma. That face was a déjà vu, as known to me as my own, as dear as my mother's, the face of a girl that had ripened for years at the back of my brain like the fruit of my soul's very self; for Tita, I found, in the helpless surprise that arrived at the end of my ten-second search, was indeed myself, a private symbol, suddenly real, for all the thoughts and desires afloat in my mind, the cult for conversion to which my life had been a single long and intricate kind of initiation. "A moon," as the poet says, "for the tide of my soul" - words that seem strange and excessive as I write them now, but describe quite accurately the state that I almost obsessively recall myself to have been in then. Among the things that change completely in the course of one's life is one's self.

The Count, of course, I cancelled out completely. I could remember nothing of what he had just said to me. I tended to ignore him anyway, since a habit of thought had made me for years consider that all his possessions were in some way really mine.

It therefore annoyed me no end to see her, in the three days that followed, as I continued my confinement to the Häuschen, seem so devoted, to see her stray from his ancient side with such obvious reluctance; and stray even then only to come bursting back, radiant with yet more obvious relief, to nestle again by his wing. Never did a mistress, in short, seem so laudably affectionate, so unaffectedly loyal and loving. I could not capture the girl's attention for a single moment. And never, 
I must add, was a potential lover as determined as I was somehow to take her and make her my own-in spite of a second obstacle, in the fact that, no doubt because of what had happened in the past, the Count effectively limited my opportunity: I was specifically reminded in a message brought by Hans the evening after that very first encounter that I was not actually to be invited to the château for three more days.

I decided to present an appearance of docility; I therefore took my meals either in solitary at the garconnière or with friends I discovered in the public places of Baden-Baden. I gambled a little, sampled the waters once or twice, had one or two exotic adventures (regarded as strictly hors d'oeuvre) and invariably found myself standing at night beneath what I had bribed Fritz to tell me was her window, waiting for the lights to go out, in a sweaty fever of sheer nympholepsia, to cure which I at one point nearly sent a telegram to an aging but skilled ex-mistress in Vienna. My second-hand knowledge of Count Julius' powers of venereal invention, at least, if not specifically of any strength still residual in his desires, served painfully to reinforce my jealous fears of what he might do in execution. For those three days I was in torment.

They, in the meantime, were inseparable. Count Julius never informed me, of course, when they intended to make expeditions; with Hans, Fritz, and the dogs, they would simply set out unannounced in the mornings or evenings. Given my condition, it was impossible for me to resist the temptation to spy. I paid Hans and Fritz generously to keep me informed of every move and followed them wherever I could, sneaking after them like some grubby would-be assassin. Thus I watched them from a distance through hired binoculars as they strolled the course at Iffezheim with the swarms of English, conspiratorially picking winners, the Count at his hopping pace, Tita swaying in the shade of his wing, moving over the shaven green with the sparkling-sweet inevitability (galling, in my frustration) of spilled champagne. When they gambled in the Kursaal at night crowding around those extravagant tables with mobs of prodigal Russians, placing each other's counters, money flowing as if the Count were some oddly beaked and bottomless pitcher of cash, I stood quietly out of sight. And on two occasions I trailed them as they mingled in the patchouli-flavoured dusk of the Lichtenthaler Allee with prostitutes, Turks, and Jews, nodding to Salamanca, Marini, Cora Pearl, and Duleep Singh. They called one day, while I loitered outside, at the Hamilton Palace to see the madcap Duke, just returned from the Isle of Wight, and they called the next at the Villa 
Mesmer to see his mother and aunt, who had just resolved their highly unfortunate quarrel. They called as well at the Villa Stourdza, to pay, no doubt at Tita's obscure request, respects. They admired as they ought the Trinkhalle frescoes, the Pfarrkirche renovations, then in progress, the views from the old and new Granducal schlosses. They went everywhere and everywhere they went, I followed, growing constantly more involved in the toils of my lust, constantly more annoyed with the Count. They were always together for those three long days and also, I presumed, for those three nights.

It seems to me that they had gone one afternoon to see the Greek Church on the Michaelsberg, though even now my memory may be playing tricks and I may be recalling a fantasy. As usual, I remember, I followed quietly behind Hans, Fritz and the dogs, entering the Church only after they left, out of sheer curiosity to see what could have been its attraction. I sat down, looked around for a moment, then dashed out and down the curving path to catch up with them again. Only later did I realize that I had stupidly left behind my stick. Returning alone in the evening especially to get it-for it was unique, a gold-knobbed inheritance from my dead father-cursing the Count for his delays and my luck at missing another hour's nearness to my Tita, I came out of the fading sunlight into the church again and paused, my eye caught by a girlish figure kneeling, lost to all but herself in the heavily scented gloom, in front of an ikon that stands near the crypt that houses the coffinned corpse of a Moldavian prince. Over her hung a raceme of rose-red lights; around her the viscous darkness flowed, laden with incense that smelled of fallen apples, freighted with death. The face, unknown, was hidden, but I could see that whoever it was was in tears, the huddled body tense with imploring, arousing, familiar.

The scene moved me deeply and I retreated, wandering back eventually to my lonely bed in the light of the new-risen moon. Later I learned that it was Tita I had seen and that if I had been less sentimental and had stayed in that Church we might have made love beneath the incurious stare of a hundred flickering saints.

The next morning I sent a note up by Fritz to confront my godfather with the urgency of his summons, telling him that both my patience and his three days were at an end. With politely expressed and appropriate remorse, he sent me back an invitation to lunch.

A dank cloud covered the sun, dimming the dregs in our glasses. The 
breeze that rippled across the terrace and around our knees turned suddenly chill. Absent-minded, I extended my arm to grasp for a plump little carmelite half way across the table and clumsily upset a fingerbowl. The scented water splashed out and ran across the cloth, spilling into Tita's lap. With a small rueful cry she rose from her chair, brushing quickly with her napkin to keep the stain from spreading over the silk. I too had jumped to my feet. "Never mind," she said when she saw my look of concern. "It's quite impermeable." At these words the Count arose and cocked his head, lifting an eyebrow, looking quizzically at her.

She shivered slightly_deliciously. "Yes," she murmured, dropping her napkin on the table, gliding into her slippers, leaning towards him and brushing one of his pilose claws with a rosy finger-tip. "I think I'll go inside and put on something warmer." In a whisper of yellow pongee that clung like a kiss, she turned, crossed the terrace and went through the French doors into the Villa. The two great deerhounds, one of them black, the other white (they followed her everywhere), leaped after her at a snap of her fingers.

"She is charming," I said with caution when she had gone.

"Who?" said the Count.

"Your niece," I said.

"Ah." He pecked at the pear again with his fork. "It's really not much of a secret, is it? She's not my niece, you know."

"I think I quite understand," I said.

"Perhaps you don't," said the Count. "Tita, you see, is really my daughter." For ten seconds I am sure I stared. Then my vitals oozed with sudden relief. What petty, banal, and rather touching circumstances had I been so madly misinterpreting? With what suspicions, plots, and schemes had I wronged both her and this kind old man? To a relationship as pure and sentimental as a Spitzweg, I had brought visions of violence. I was ludicrous. How could I have been so mistaken?

"But there is more to it than that," he went on imperturbedly. "I did not ask you to meet me at Baden-Baden just to talk about Tita," he said, rising from his chair, drawing his black gown together, gathering up his gold-knobbed stick. "No," he said, "I have asked you here for reasons that I consider, perhaps egotistically, much more important than that, reasons that I have been mulling over for several months. Forgive me," (suddenly turning towards me, his black robe flapping to his sides) "forgive me, Hugo, for making you cool your heels, as it were, for the past three days. But I needed more time. You came here for my sake, 
because I asked you; and I asked you here for the sake of your dear dead mother." His voice, surprisingly, halted, croaking, as if he were in fact on the verge of tears. "She was very dear to me." He collected himself. "Come," he said, "let's go up to my nest where we can talk a little more privately. Ordinarily I do not allow even the servants to come there."

I rose and followed him in, entering the Villa for the first time, eager to hear whatever he might want to say, but more in hunger for the merest glimpse of Tita, wondering how the different light she now stood in would change my vision of her. Nor was I to be disappointed.

Part II

Nothing could be heard but the mewling of pages and lamentations of sultanas.

-Beckford

Es is incroyable, Fürstin! Ihr Wagen scheint ganz introuvable zu sein!

-H.R.I.M.F.J.

The Count's château, as I then discovered, was a curiously constructed place, and I hope I may be excused for describing the Villa Falkenberg a little here.

Fundamentally, it was a series of high and ornate salons joined end to end, rising by marble degrees up the side of the mountain, and forming thus a single long, glittering, tunnel-like passage. The French doors from the terrace through which Tita had gone, for example, led into a kind of drawing room, gorgeously furnished in Buhl of the Régence, from which one could therefore see, by looking to right or left, the entire length of the house, the unlit lamps of the Villa rising on one hand and falling on the other in tiers, descending on our left to the faraway filtered daylight of an orangerie, ascending on our right to a darkness only distantly lit by a pinkish monad glow. "This way," said the Count, and in that direction, hopping on ahead of me, he beckoned. From somewhere came muted music. 
We mounted a short flight of stairs and encountered, first, a second drawing room likewise furnished in Buhl, exactly, in fact, like the first, as if it were the same room seen in a glass, except that the French doors here stood on the opposite side and led, as the Count informed me, into the small foyer at the front of the house. "Perhaps you noticed," he said, "as you came up the drive on your first day here that my house looks like a stairway on the side of a hill. Many people have said so," he went on, "but they have been unable to tell whether it went up or down." And he chuckled, glancing up at me with his corvine eyes. "The park is level enough," he continued, looking at me, "for all its surprises, but the house is a different matter. And I like it this way."

The next flight of marble stairs led up to a ballroom, where a strange sensation as we crossed the parquet floor, a feeling that the Count and I were not alone, made me look upward: the entire ceiling, one gigantic mirror, reflected the tops of our heads and shoulders as we walked along, and the patterned parquet moving beneath our distant feet. "On the roof," said the Count, "directly above, is an artificial lake. Not more than a few inches deep but quite pleasant to sit by in the summer and look at the stars in. I am thinking, however," he added as we mounted a third flight of stairs, "of having it drained for good. It is rather unclean - stagnant, you know_and what's more it sometimes leaks. Bad for the parqueterie. I used to bathe in it once."

For many minutes I had been vaguely aware that the muted music was gradually growing louder as we moved. When we entered a dining salon-unremarkable save for its row of windows overlooking the rising height of the mountain and for the Meissen épergne that stood halfway up the length of the glistening table, representing with considerable size, force and ingenuity an interestingly obscure mythological motif, the conception and birth of the pastoral Hermes: so the Count-I could begin to identify the sound as floating from some sort of organ and the music itself as something I had once heard of Liszt's with the usual "czigány" in the title. Count Julius drew my attention to the épergne, explaining its subject, and to its central bowl, which mimicked a large and patulous primrose and was heaped with a cluster of small beaming apples. "From Carthage," he remarked. "I have them sent every year for Tita. Perhaps you would like to try one later?" He looked up at me and blinked.

"Does Tita like them?" I asked probingly, attempting to return to the sole subject of interest among all his cryptic remarks. "They remind me of her." 
Count Julius started, as if I had blurted out something slightly obscene. "In that case," he said, "for you to eat it would be a kind of vicarious cannibalism, n'est-ce pas?" The muted music suddenly faded and stopped.

From the fourth flight of stairs we entered a windowless room: a bedroom - for such, to my surprise, fond as I am of a current of nocturnal air, the Count assured me it was, though lacking the usual bed. Here I found the source of my music. "A bed would be useless," he said with a rueful shrug. "I suffer from semi-senile insomnia. That's why I need Jószef here to help me get to sleep." He gestured to a corner, the darkest in the room, where a figure was rising from the bench of a small pipe organ.

"How can he see?" I asked, for the only light in the place was the pinkish glow that had seemed to grow slightly more vivid as we moved through the house and that faintly shone through the lone doorway at the other end of the room. A weirdly limbed candelabrum, stuck full of tall unlit candles, stood nearby on a low oriental table.

"You'll see," said the Count as the figure came limping towards us. "Jószef!" he called, "Húzd ra czigány!" The figure seemed to cringe, then came uncertainly forward. It was a man, a powerful-shouldered hunchback with a young, eagle-like, even noble face surmounted by a crest of radiantly snow-white hair. He was dressed in black; and he came toward us limping, first in one direction then another, as if not quite sure where to go. The Count clapped his hands. "Very sensitive," he remarked to me out of the side of his mouth. "He can actually feel the concussion." And indeed, the hunchback stiffened, straightened slightly, then smiled, almost angelically, turning his face toward the Count, and made a kind of bowing crouch in his direction before scuttling noiselessly out of the room. "Blind," said the Count, "and very nearly deaf and dumb. Congenital. A hopeless case. Utterly hopeless but for his relationship to me. But his situation here is perfect."

"Ask him to play again," said I.

"I would," said the Count. "But he, of course, poor boy, couldn't hear me. He can't even hear the music that he plays. But he knows his appointed times. He'll be back again to play at midnight."

He turned to the rest of the room. "I have spent some happy hours here, with Joszef to help," he continued. Three of the walls were hung with plum-coloured velvet drawn back by black silk cords only at the two opposing doorways, the one by which we had entered and the one 
by which we would leave. Drawing it back at another place, however, the Count exposed examples from a rich collection of pictures, including-apart from a Titian Venus-a Romano Thetis like the one in the Palazzo del Te, two Primaticcio classical studies, a Bronzino "Amor Bestialis," five delightful little Fragonards, and an extraordinary Caravaggio depicting three Neapolitan sailors, a duck, and a chest of drawers. "The pictures are rather specialized," said the Count. "And there are far too many. All around this room. Nearly a hundred. I keep them covered. And yet they provide," he went on, "a kind of inspiration. Or, if you like," he smiled, "a spiritual uplift. I find as I grow older that I need that sort of thing."

Against the uncurtained fourth wall stood a row of five huge Spanish cabinets, with six great pier-glasses filling all the intervals and remaining space. The black and white stone floors were covered with bearskins and the only ameublement otherwise was the low Eastern table, with its candelabrum, and a large adjustable heavily cushioned leather-covered chaise-longue, outfitted with various slots, straps, levers, knobs, and stirrups, of a kind resembling the sleeping-machines one sees in a Swiss sanatorium. "I find this engine very therapeutic," said the Count.

It struck me at the time that the room as a whole was a remarkable reflection of the old man's character as I had known it. But there was much of that character that I did not know, and which I only learned of in the later passages of that day.

Passing up through parted velvet, we now strolled directly into a barrel-vaulted hall. "A joint production," said the Count, indicating the frescoes that covered the whole surface of the unbroken walls and ceiling, "the fruit of a collaboration between Coglioni and De Toite. In many respects it's quite unique." I saw little, however, at which to marvel: the usual hispid-shanked horse- and goat-men were busily raping the usual fruitily buttocked and bosomed nymphs, the former ithyphallic and ruddy, the latter patent to the point of raw complicity. In fact, as the mass of orgiastic flesh swept whirling up for the lefthand wall, and over and down to the right, their roles of relative aggressiveness seemed to reverse, amounting in the center of the ceiling to a polymorphous melee of mutuality. "You must see it at night sometime," said the Count, "by candlelight or torchlight." I did see it in fact on a couple of later occasions and the effect was-perhaps still is-quite spectacular. We went on.

Just before we reached to the top of the next flight of stairs, a 
maidservant in peasant dress passed us going down, carrying a covered basin, bobbing her ribbons at me and the Count as she hurried by. I followed her momentarily with my eyes and I could see beyond her, far down the descending vista of rooms through which we had come, the black form of Joszef, steadily heaving as it grew tinier in the distance, moving towards the orangerie.

When I turned around to follow the Count, I thought we must be in Paradise.

Two great deerhounds scrambled to their feet. Here the walls were of satin, dimpled and pink, and were hung at apparent random with hundreds of variform mirrors, each giving back the lights of a great low-slung chandelier whose myriad of candleflames were shaded with rose-red glass. The room was Tita's windowless boudoir, in whose center she sat with her back to us, the yellow silk dressing gown peeled from the pearly putamen of budded torso and falling over the stool on which she sat. Thus nude to the waist in front of a movable looking glass, her hair undone for a Dirndl to brush its black-foaming gipsy length, the brushback glinting with every stroke, she glanced up, saw our reflected images as we entered, made a small and inscrutable ruby moue. The maidservant looked at us, squeaked in fake alarm, then grinned conspiratorially.

"Are you warm enough, my dear?" said the Count with solicitude. "Shall I have them bring you a brazier?"

"No," she said as she languidly wrapped herself in the gown and turned to face us. "I'm quite warm enough in here."

"Very well my dear," said the Count. "I'm taking Hugo up to the tower."

I bowed and then faltered, but he drew me along, with a clucking noise, by a sleeve. I confess I neither heard nor saw anything for the next several seconds. Memory tells me that this vision of Tita had simply overwhelmed me. The knowledge that she was his daughter had changed nothing.

When I came at length to my senses, I was at first conscious only that we had climbed more stairs, that from somewhere came the sound of running water, and that wherever we were it was dark. The Count was lighting a taper. "At this point," he was saying, "the Villa bridges a swallet, an underground stream. We are now within the side of the mountain. Be careful and stay close to me."

For a time we seemed to walk in a kind of tunnel. Its walls were 
damp, its air was curiously clammy but warm, and its floor continually slanted upward. At length we came, as I saw in the gleam of the taper, to the foot of a crude stone staircase. "The last we shall have to climb," said the Count.

The ascent was sharp. The stairs were steep, their stones worn and slippery. Shortly the sound of running water decreased and ceased. The Count spiralled on ahead of me, puffing a little, one hand drawn up and clasping his wide black sash, the other holding the candle, which illumined as we climbed a series of brazen statues stationed in niches some twenty or thirty paces apart: Demeter, Persephone, Danaë, Leda, Europa, Theophane, Ganymede, Io and Tyro. The air began to grow fresher, as we coiled at the Count's pace steadily upward in the dark. At last I saw a patch of daylight ahead and after some thirty more steps we halted by an open window where a gust of breeze extinguished the taper. We stood on a landing before a small green door.

I looked out the window downward to the terrace where we had had lunch. Hans and Fritz were busily clearing our table, their heads and shoulders no bigger as seen from this height than the crumbs they tossed to a scavenging flock of pigeons, whose sudden surprised ascent filled the humid air between them and me with the white clatter of their wings. I followed the birds with my eye as they flew over the wall to the peacock-and-piney garden.

Beyond the garden, beyond the park of the Villa to the West, the Schwarzwald rolled in early-autumn mist, its black and tenebrous firs stretching mile after mile to the silvery running stretch of Rhine that steals from Strasbourg to Speier. Closer below lay Baden-Baden, its rooftops, towers, and steeples spread servilely out to the New Schloss' spurning foot, bald and bare on its height to the north. Mountains meanwhile rose near at hand, from whose direction along the road that bordered the park and led to the Mercurius-Berg, intermittently visible through the trees, came a caravan of Zigeuner, an irregular file of painted wagons, women afoot in bright-colored skirts and men on horseback, arriving from God knows what Transylvanian reaches, the creak of wheels and the chime of pots and pans hung at axle-trees coming obliquely faint through the distance at their approach.

"Laetzi," muttered the Count on the strength of a downward glance. "Long-haired, vicious, and dirty. I must give orders at once to send them away. They do not belong here." Behind me he unlocked the door and murmuring, "My aerie," invited me inside. 
The room was small, light, and perfectly round, its single wall buttressed to the height of my knees by a low horsehair-covered banquette whose circuit was interrupted only by the doorway in which I stood. Through a ring of windows opened outward above the banquette one saw only a vast expanse of sky, where a few clouds were teasing the sun with a threat of rain.

"Well," said the Count, spreading his arms in their winglike sleeves, and gesturing broadly with his gold-knobbed stick, "here we are! How do you like it, Hugo?"

"It's charming," I said. "One has a sense of absolute freedom."

"Oh, quite right. The freedom of an eagle. We cannot live without freedom." The Count had read a lot of German poets.

"And I think your daughter is also charming," I added boldly.

He suddenly turned his attention upon me, fixing his avid eyes full on my face in query. "Are you-interested_in her?" he asked.

"Yes." I said.

His face cracked across the middle; he was making a sudden smile. "And are your intentions-honorable?"

I was, admittedly, flustered. "I-I don't know," I stammered. Then, "I love her."

The Count stopped smiling and drew back. "You love her," he muttered. "Perhaps some day," he said louder, turning away, "she will make some lucky man a very good wife. But that man," he added, turning towards me again "will not, I trust, be you."

"Why not?" I said. "What's wrong with me?"

"Why, nothing," he said, "with you, my dear Hugo." He raised a hand to keep me from crying out. "You are not quite so perceptive as I thought," he went on. "She is, I told you, my daughter. And as my daughter she is able to afford me peculiar pleasures, pleasures which it is given to few men ever even to recognize, much less to enjoy; pleasures whose significance Tita herself, in her ignorance of her true situation, does not in the least understand, pleasures whose intensity is increased by that ignorance. Or call it, if you will," he smiled, "her innocence."

"You mean," I said, "that she doesn't know?"

He ignored my question. "Tita belongs to me. She will belong to me until I die or until, as is more likely, I grow tired of her." Could he see that I was stifling? "No, no," he said. "I am too old, where matters of the senses are concerned, not to be cynical and selfish - and selfish to the point of what may seem to be ruthlessness. Do not speak to me about 
Tita any more. I am gratified that you find her charming. Do not speak of her any more."

I can almost feel now the effect this conversation had on me at the time-the thunderous recognition that I was being forced to accept the fact that this mephitic old vulture could be both her father and her lover. It fell on my soul like a great avalanche roaring into a mountain pool. I was staggered. My legs rippled, my knees went watery. And my thoughts flew to her, for I knew now that the poor child was under the spell of a monster. But how could I rescue her? Speechless, I groped my way to the banquette and fumbled for a cigar.

Ignoring my reactions and advancing now to a writing table that stood in the middle of the room, Count Julius beckoned me to be seated, as if nothing had happened, then turning, took up a large and beautifully lacquered box.

"Is the wind too much for you?" he asked, appearing to note my state for the very first time. "Perhaps I'd better close a few windows. It looks like rain." He handed the box to me. "Hold this for me, won't you Hugo? I have quite forgiven you already. And there is something inside that I have decided at last to show you." Kneeling on the banquette and leaning past me over the casement, he reached out on either side for the latches by which to draw the window to.

It was his last voluntary action. Without thinking, still holding the lacquered box and hardly bothering to shift my weight, I had only to nudge him slightly. With a gasp, he floated outward and was gone.

My gaze stayed fixed on his slow descent. I recall how I watched his outspread arms in their black sleeve-wings and how for one absurd second I felt myself fear that the wicked old man would take flight, would transform his fall to a swoop and return, like a monstrous bird of prey, to take me to task for my deed. Indeed this fear still comes back to me now. But the flapping black of his robe grew steadily smaller and smaller against the white paving stones of the terrace until at last, the merest speck, it expanded slightly, then altogether, gratifyingly, stopped.

I began to breathe again. Still completely unthinking, I crossed the room, opened the little green door, and rapidly descended, arriving at the foot of the stone stairs, despite the dark, in what seemed no time at all, making my way down the house as if by instinct, through the damp passageway to the doorway of Tita's boudoir.

I stumbled in. She turned as I entered, startled. I halted in mid-stride. The lacquered box was still in my hands. Again the two great deerhounds leapt to their feet. 
"Count Julius" I said, "is dead."

Tita looked up at me, bright cheeks paling, fingers fluttering to her rose-nibbed breasts as she dropped the silver-backed hairbrush. Sloe-dark pupils floated upward in fringed sockets; and with a little cry she fell from the stool, in a swoon, to the lake-colored carpet. The two little maidservants screamed and bolted.

I felt the way the prince would have felt in a version of the old peasant tale if the virgin princess had for some reason failed to wake from the wicked ogre's enchantment: a plot from which I had every right to expect somehow instantaneous gratification had been hideously turned against me. There she lay with limbs quaquaversal, sprawled and deathly still. I dropped the box on the floor, watching mutely as it sprang open on contact and emitted a large and elaborately fashioned egg, gilded and jewelled, the unmistakable work of the notable Fabergé, which rolled across the floor and came to rest at the foot of a full-length mirror. Throwing away my dead cigar, I ran to a bell-rope and tugged it till it came away in my hands, then ran back to Tita, knelt by her side, and began chafing her wrists, first one then the other, desperately trying to revive her, feeling already a momentary remorse for my reckless deed.

These first efforts proved to no avail. Her eyes remained closed, she sighed, and seemed to have difficulty breathing, which made me turn my frantic intent to the knot of her dressing-gown cummerbund, to loosen it for the sake of this laboured respiration. It would not yield. Leaping up in frustration I dashed to Tita's dressing-table, where I found a tiny silver knife, thrusting which into the knot, and witlessly sawing backwards and forwards, I quite soon cut the cummerbund through.

When its severed ends flung aside in a flurry of silk that settled with barely a whisper around Tita's form, the whole of her charms, ripe and pink and white, lay suddenly rendered to my view. And it struck me that here I was, without having planned it, on the verge of victory. I started back and arose, thinking of the servants and attempting to keep my hungry eyes on the rove. But they rivetted helplessly, reaching like hands toward forbidden fruit, to where long legs joined a grooved belly at symphysis pubis in a light copse of girlish lanugo.

At this point Tita's eyelids began to flutter. "Water," she sighed. From a carafe on the table I poured out a gobletful and held it as carefully as if it were my soul to her lips. She swallowed once, twice, then opened her eyes, which seemed, through their incipient tears, to thank me for my attentions. She smiled and murmured, "Enough." I 
set down the goblet and, slipping my arms beneath her quivering limbs, lifted her up, and carried her to her bed, where I gently laid her down and covered her, propping her head with a pillow. As I backed away, respecting the approach of the servants, "Don't go," she smiled, "Stay here with me," patting with one hand a place beside her on the madderand-pink patterned counterpane. "Here." I at once acceded to her request.

"How did it happen?" she said.

"He fell," I said, "from the tower."

"Oh God." She lay back. Her anguished face was violently attractive. A tear formed and ran down one cheek, looking, as her color came and went, like dew on a nectarine or glabrous peach. "I knew it," she sobbed, "and so did he."

I was puzzled. "But how?"

"A fortuneteller told him in Braşov-or was it București? - three months ago. He knew he was doomed."

I smiled in spite of myself at the girl's naiveté. "Did he believe it?"

"Of course he believed it," said Tita solemnly. "And so did I. Oh, I tried to take care of him!"

"But somehow the Count never struck me as the sort of person-"

"I loved him!" she cried and buried her head on my shoulder. I put an arm around her. The bedclothes fell away. Her shoulders huddled beneath my embrace. I put my other arm around and held her close, while she heaved and shivered, clinging to me, weeping on my shirt front. I looked up at our reflection in a mirror overhead, then glanced down at the two pink-nippled pomes that were trembling against my sleeve. Five lines of Latin verse danced inescapably through my head:

Vaginula, anima blandula, Hospes comesque corporis, Quae nunc abibis in loca, Pallidula, rigida, nudula, $\mathrm{Nec}$ ut soles dabis jocos?

At length her sobbing ceased. I gave her my handkerchief. Wet-faced, Tita looked up and smiled.

"What will you do now?" I said. "Where will you go?"

"I don't know. I have no place to go. He was very good to me."

"But what did you do with the money he gave you?" I knew the Count was a generous man. 
"He didn't give me money," she said. "He gave me-things." Her lips opened slightly and puckered; she seemed on the verge of more tears. "He was such a kind man!"

There was a pause. "Why don't you come with me?" I said. Another pause.

"Did you know," I said, "that you are Count Julius' daughter?"

After a third pause Tita said very faintly, "Yes."

There was silence.

"Never mind," she said. "Hugo, would you get me my guitar? I want to sing a song." her.

The instrument hung by a bedpost. I untangled it and handed it to

"Do you know the one that goes, "Fire, fire, tranda-fire, dar tu ce te-ai zabovit'?" she asked. I nodded. "Then I will sing something else."

Her voice was like a nightingale's, throaty and soft, as thick and sweet as honey.

\author{
Primavara cînd soseste, \\ Neica la plug îmi hăieste, \\ Mindra la pînză-mi nalbeste. \\ Cine-i om stunci traiesté \\ Si ce-i place tot iubeste. \\ I-auzi, mindro, turtureaua! \\ S-aide sa'nfudam vilveaua, \\ S-apoi mina, badeo, mina! \\ S-apoi mina, badeo, mina!
}

She sang only one verse, repeating the refrain's last line, then put down the guitar. I understood.

It was, as a Frenchman might say, a coup de foutre. My arms again were about her. She fumbled at my cravat, clumsy and urgent. And such was our common passion, as I plunged in her up to the haft, that my too immediate spurt drew a gasping cry of relief from Tita as well. "Don't leave me," she sighed. And we stayed thus locked, entreating those pulses again and again with lengthening satisfaction as the afternoon wore on, while the deerhounds alternately played and dozed, and the dawdling servants peeped in from time to time through the doorway.

At five o'clock, white-gloved Fritz brought tea and fresh candles, and timidly announced that the local authorities had called to ask questions 
probing into the death of the Count. Reluctantly I arose from my bed of pleasure and stepped to the floor, only to find that Tita's dogs at their play had ripped my clothes to shreds. Among the tumbled rags lay my cigarcase with its seven slots, four of them empty.

"Never mind," she said with a crimson yawn. "You'll find some dressing gowns in there." She pointed a lazy finger at a painted armoire that stood in a corner of the room. Opening it, I discovered what appeared to be fifty dressing gowns, all but one, of sky-blue silk, in shades of black and obviously made for a man. I did not enquire whose they were or why they should have found a home in Tita's boudoir, but chose the blue one.

"Que tu es brave," she said.

"Tu es surprise?"

"Rien ne m'étonne," she said with a little smile.

"Tu es mon âme," I said, "ma pêche adorée, mon péché mignon." I knelt on the edge of the bed and embraced her.

"Hugo," she murmured, "I love you," and gave a delicious shudder.

"But mademoiselle," I said in a regrettably jocular tone, "we hardly know each other."

"Listen," she said, taking my head between her two little hands and looking deep in my eyes, "sometimes there are two people who never can be strangers. I knew when I first met you that I had known you forever, that if I'd never met you something in me would have died. Didn't you feel that?"

The force of her convictions ran like a stab to my heart, the sharper because they so completely matched my own.

I confess that I remember myself to have been rather savage with Tita. In the stress of my passion for her, all I had learned of subtler love was lost, went flying, as it were, out the window, leaving me only the will to abandon myself, to gratify my desire, which was simply to have her and make her have me. Wit, humor, tenderness, disappeared, drowned in the tide of my lust, my will to possession; and the act of love itself became meaningless to me except as it meant Tita.

But was I wrong? Lust, as I have learned and relearned since then, is a truer guide to the soul, the tribute of a heart uninhibited. Unspontaneous, love makes allowances, but lust does not. Love means investment, continual acts of sacrifice of the self, futile attempts to build a bridge between two souls that inevitably stand apart. With lust, on the other hand, there are no such surrenders, only the fight to have and to 
hold, to seize the fruit, to squeeze it and drain it, a fight that two should wage, not against the difference between themselves, but against the dust of eternity. Tita understood these things, and understood me, I think, as well. Parched by the presence of death, our thirst was great and mutual and so was the liquid heat of our response. Show me a man and woman who lust and I'll show you the molten core of life.

Some of these thoughts came to me as I went down the stairs through the length of the château to where the police waited, beyond the Count's bedroom, the dining room, and the ballroom, in the foyer outside the second drawing room. I explained to them-a pair of rustics whose investigative industry seemed almost wholly confined to their identically byssid nostrils-how the old man had stumbled and fallen, described his helical course from the height of the tower in detail, and at last, when they seemed satisfied, returned to Tita. She was sitting in bed with the Count's egg in her lap, nibbling a macaroon, her natural charms in my eyes making strange contrast with the flashy presence of Fabergé's cunning piece as it nestled against the dewy pell of her belly and thighs, nuzzling that tender holt.

"I'd forgotten," I said as I climbed into bed, "about that."

"Let's open it," said Tita, clapping her hands.

"Give it to me."

My hands moved over its curving surface, feeling gently among the encrusting gems for a catch, until my fingers had searched out a tiny crotchet, and gave it a tweak. The top sprang back, revealing a bunch of papers tightly tied up in a length of black silk ribbon. I lifted them out and plucked at the ribbon, but the knot would not yield. I handed the papers to Tita; and as she with her smaller digits and longer nails undid it, they fell apart: a legal-looking document on heavy foolscap and two letters addressed to the Count, of an obviously older date.

I took up the first of the papers.

"Read it," she said.

Running to many pages and couched in the jargon of a Viennese attorney, it was almost an unreadable thing. The first paragraph was enough, nevertheless, to tell me what it was all about.

"It's Count Julius' will," I said, feeling my heart miss a beat.

I read the second paragraph.

"We are his heirs."

Tita looked at me blankly. To her he had left a Galician estate and money enough to make her rich for life; to me went the place at 
Baden-Baden (which, by the way, I almost immediately sold), some scattered lands in Moldavia, and the house in Paris where I had so often been as a child. Quickly I skipped through the rest of the will, pages of bequests to women and servants, until my eyes were stopped by the words in the next-to-last paragraph. "And to Jószef Nagy," I read,

a musician on my estate of Falkenberg near Baden-Baden whom I now acknowledge for the first time as my son by one Eszter Nagy, a prostitute of Buda-Pesth, I leave the residue of my goods and estates, in the hope...

Amazed, I read the words aloud to the end, then looked up to see Tita blush, from the roots of her jetty curls all the way down to the pinkpointed nodes of her paps. Then she gasped and burst into tears. "He was so generous! We are wronging him terribly!"

Undeterred by this storm of futile remorse, I comforted her as best I could and picked up the first of the two letters. Like the will it bore the heading of a legal firm and was written in attorney's German; the offices of this firm, however, were not in Vienna but Kronstadt and the date was 1851. After the usual obsequious salutation to the Count, it ran literally as follows:

In Regard to the erstwhile of Batabrâdet the of Your Excellency's near Jassy Estate Woman, Ileana Livada called, we Your Excellency that, in View of the by Voivode Stourdza in 1844 giving to Serfs and Vagrants Liberty Proclamation, Your Excellency cannot over the Body of said Woman seigneurial Rights legally claim, beg. With particular reference to the Maria called of said to inform Woman Offspring female Infant we Your Excellency to inform that, said of 1844 Proclamation Your Excellency's over the Body of said infant Child seigneurial Rights likewise invalidates, further beg. In View of the Facts, primo, however, that, said Ileana Livada has, in effect abandoning said female Infant, From Your Excellency's Estate of Batabrâdet removed, and that, secundo, Your Excellency has himself of said female Infant the Father graciously acknowledged, we have the in accord with Your Excellency's wishes as of said female Infant Guardian Your Excellency establishing Proceedings to institute Liberty 
taken. We Your Excellency that, these Proceedings successfully concluded have been, to inform beg.

Several signatures followed. Below the signatures a note was appended as a kind of postscript in French.

26 October 1851

Our search for Ileana Livada has been fruitless. As far as we can gather, she appears to have gone with her kinfolk into Transylvania. We believe, with all respect, that a further search would be equally fruitless.

It was signed by someone who bore the same name as one of the listed partners in the firm.

Silently I handed the letter to Tita, translating the first part for her benefit over her shoulder. When she had read the second part she turned to me. "Ileana Livada was my mother," she said very simply. "I've never seen her. Until six months ago I was always at school." She suddenly lifted her arms, raising and spreading her hair and letting it fall in vapour around her shoulders and breasts, then lay back among the pillows, regarding herself from its smoky frame in the mirrors that hung on the underside of the canopy, quietly pouting at herself as if lost in momentary reverie of something vaguely and personally unpleasant.

Hoping that she would not choose to weep again, I picked up the other letter. At first it made no sense to me at all. It was dated from Paris, 20 July, 1845, and was written in Magyar. "Darling Gyúla," it ran:

I have decided, not without some qualms, at last to forgive you for having run away after the christening. Do come and see me. The child is here with me now in the care of a wet-nurse. I should think you would be rather proud of him. He looks just enough like my husband for Károly to be completely deceived but not enough to cease to remind me of you. He has your hair, you know, and your eyes, and even some traces of your luxurious disposition. Oh, how much he reminds me of you! Do come and see us both. He's growing fast and it would make me happy for you to see him now.

Affectionately,

A. 
My father's name was Charles, like the husband's in the letter. Indeed, as I read it through, the whole style seemed at once oppressive and, literally, familiar. Then I realized that the signature, which I had seen a thousand times on letters addressed to everyone from reigning monarchs to the headgroom of a stable, was, of course, my mother's. What could one do? I leapt out of bed and began pacing back and forth.

"What's the matter?" said Tita.

"Nothing," I said, "except that you are my half-sister."

She stared at me wide-eyed for several seconds, an expression I always find arousing. "That," she said quietly, finally, "explains a very great deal." Suddenly, her face blossomed into a radiant smile, and she held out her arms to me. I crossed the room, my bewildered heart at full flood, and knelt among the bedclothes, seizing her in my arms. While hot little fingers closed on my swelling yard, I bit into the petals and fruit of her lips and mouth, then plunged into the glissid clutch of her gynaecium.

Hours later when I awoke the pillow beside me was warm, but empty. The air was filled with the sound of organ music. Next to the flickering night-light on a table beside the bed stood a half-eaten dish of rose-petal sherbet. I ate it and waited for Tita's return. I waited for what seemed hours and finally dozed.

I had a dream. I dreamt that I was on a train, travelling across a flat featureless landscape, a high plateau; I was standing by myself in the aisle of the train looking out of an open window, through which came a hot wind full of dust. The sun was high; on the far horizon there were only the wretched silhouettes of a few stunted wind-blown trees; the intervening ground was stony and dry. There was little to look at. Ahead, I noticed that the locomotive hauling my car was curving. Then we seemed to be crossing a bridge over a deep gorge, for looking down, I could see a river far below, a narrow ribbon of deep rocky blue that showed the $\mathrm{H}$-shaped shadows of the trestles holding up the bridge. And when we were just over mid-stream the train itself seemed to stop.

There was a pause, then down the aisle came a bearded guard in uniform, tapping on each of the compartments with a short baton. One by one, the doors as he passed them opened, and out of each compartment came a flock of tropical-looking birds, which then flew out the train's open windows, making wild screams and calls. As the last of the birds flew off, the guard disappeared, and as if that were the cue, a terrific thunder-storm arose. I felt the train swaying under my feet, as the bridge gave way to blasts of rain and wind. There was a loud crack and the floor 
of the train seemed to sag. Then everything began falling. My feet slipped out from under me and I went sliding head over heels out through the open window, falling down through the air.

What happened near the end of my long descent was that I seemed to sprout sudden wings, great blue sails that bore me up in the gale, just in that second when I seemed about to strike the rocky surface of the river. I swooped up; and behind me as I rose I could hear the bridge and the train falling together with a crash, while I myself glided majestically higher, then flopped along, following the river's course below me.

I followed high above as it wound across the desert plateau, miles and miles, until it flowed into a fertile delta, spreading out to water what appeared from my height to be thousands and thousands of flowering trees, growing on hundreds of small closely scattered islands. The scent that arose from the blossoms as I wheeled in the air was overpoweringly intoxicating, even to a bird, but more than anything I felt myself suddenly overcome simultaneously by fatigue and a maddening thirst. At this moment a delicious pain went through the center of my chest and by cocking my head I could see, protruding from it, the neck and feathers of a silver arrow. I felt myself falling again.

I seemed to drift down softly, landing painlessly on my feet among the leaves of a blossoming tree. As I came to rest, my feet touched the feet of someone else who I somehow knew had also here come to earth, reclined already among the flowers and leaves. It was Tita, stretched out there in the foliage above the ground with her arms spread wide, looking up at me and laughing. And she too had a wound, a pair of tiny red lips pouting vertically in the little hollow at the base of her throat.

"You have a wound," I said, standing poised up there in the tree.

She said, "You have a wound," and laughed.

As I looked down at her and as she laughed I felt the arrow in my chest slowly reverse and then extend itself, so that what protruded was now its triangular point, which changed its shape, growing larger and larger, until it turned into a knife, and suddenly was no longer attached to a shaft, but rested in my hand. I knelt down between her knees. Bending over her I carefully inserted the knife to the hilt into Tita's little wound, then drew it in one continuous deep red line down over the sternum between nippled half-globes, over the diaphragm and upper belly, down into and up out of the chaliced navel, down the lower belly, up the rise and down the woolly slope of the mount, withdrawing only below that crinkle where nether labia began to make their own rosy 
parting. Tita continued to laugh. As I lifted out the blade the line I had drawn began to widen like the crack in the middle of an opening double-leaved door, the two halves I had made split away from one another, the silky skin rippling back on either side, and muscles and ribcage in two parts unfolded in a corolla.

I was bent over her again, my yearning tongue-tip just beginning to taste, when I awoke.

After several seconds my blind hands grasping at empty bedclothes made me realize that she still had not returned. The organ music had stopped. My mouth seemed to taste of pomegranate. I climbed out of bed and threw on the blue dressing gown impatiently and with small address, for I had been aroused by my dream, and was painfully tumescent. I shouted her name.

There was no answer. The sheets exposed where the eiderdowns fell back bore the impress of Tita's body, shallow where the shoulders had lain, deep beneath the toss of those gipsy loins. It was only, of course through imagining eyes, confusing Tita with a Parisian débutante of the year before, that I saw in that depth for a moment a dark red stain, like the juice of some ripe intoxicant berry or a freshly-plucked and plundered hymenal calyptra: Tita herself had told me that afternoon that she had been raped at the age of eleven by a non-commissioned Polish Hussar who smelled of radishes.

I picked up the night-light, haunting myself as I did so, with a thousand flickering pinpoints' gleam in a thousand faceted mirrors; and left Tita's bedroom, resolved to walk down through all the dark and silent rooms of the château until I found her.

On the walls and ceiling of the barrel vault leading from Tita's room to the Count's, the painted figures seemed alive, writhing in a fury of copulation as my light passed over them.

The Count's bedroom, by contrast, seemed as still as an abode of the dead. With my lamp held before me, I passed along the row of cabinets and mirrors until, in front of a pier-glass, I saw a flash of white in the middle of the room, and at the same time observed that the double doors of one of the Spanish cabinets hung ajar. Turning away from the cabinets and mirrors toward the center of the room, I could just make out that the flash I had seen was a human form, reclining. And as I stepped toward it the night-light held high revealed my new half-brother, Jószef.

He was stretched supinely, strapped to the sleeping machine by ankles 
and wrists, marmoreal against its midnight-black padded leather, like a sculpture of some clumsy Hephaestus, perhaps trapped in the same venereal toils that he had laid as a snare for his rival. Across the purple-bossed pectoral bulges, the slack belly, and the thick furry thighs ran the scarlet lacings of a well-administered scourge, against the repetition of whose blows only a donkey-like member, acting on its own, appeared to make listless protest, as I watched, by jerkily rearing its enflamed-looking finial.

Jószef, of course, neither saw nor heard me. I looked around. His dead-black clothes were neatly folded and stacked on a low Near Eastern table nearby. Next to it, on the floor at the foot of the sleeping machine, stood a weirdly branched candelabrum with all its seven candles burned down into the sockets. And next to the candelabrum lay something else, a small yellow heap. I touched it. It was silk. I picked it up. It smelled of love.

What right had he? The answer was: none. Almost blind with rage, I stepped to the Spanish cabinet, selected a random stout birch rod, and gave Joszef, before it broke in my hand, a dozen or so of the best, which he greeted, by now quite peduncular, with an angelic smile and an inarticulate moan.

In the dining saloon someone had smashed the Meissen épergne, scattering bits of primrose porcelain the length of the room. As I stooped, Meleager-like, to retrieve a Carthaginian apple, the corner of my eye caught sight of something that made me start with such violence that I nearly extinguished the night-light in my hand-fortunately I did not drop it-something crawling beneath the table, discernible only as a black shape.

My heart was pounding as I crept closer, while my mind sprang open like a suddenly unshuttered window upon the vision of Count Julius winding his leisurely way down a column of air. Steeling myself, I was prepared to discover that I had seen the old man himself under the table horribly crippled but still alive; I crept closer. And from beneath the table and bounding between my legs in a rush came a howling apparition, the coal black half of Tita's couple of deerhounds. The dog ran down the steps to the ballroom and disappeared.

I shouted for Hans, Fritz, for any of the servants. Not a sound. I was becoming a little dismayed, no longer knowing quite what to expect or what to tell Tita when I found her. It occurred to me, of course, that I could turn back and look for her in the tower, where she might have 
gone and from where she would have had difficulty hearing me. It was the dog that led me on, however, for its flight was the only reasonable indication of the direction Tita had probably taken. I followed after.

In the ballroom so distracted was I by my image reflected in the ceiling that I stepped barefoot in a puddle of tepid water. Hastily recalling the Count's misgivings about the pool on the roof, however, I did not stop to investigate, but hurried on, ignoring the other nightlight held by the upside-down walker over my head, descending first to the second drawing-room and secondly to the first, occasionally softly calling Tita's name.

Here I found two clues that momentarily halted me, suggesting that I should not have to go down all the way to the orangerie to find Tita; for the French doors leading to the terrace where we had eaten lunch were flung open wide and in the center of the opening lay two halves of the Fabergé egg, facing each other like a pair of bejewelled Huysmanian tortoises. "The old shell game," I thought as I turned first one over and then the other and found them both empty.

I went past them out onto the terrace and stood for a moment peering in all directions. The night was as dark as the inside of the château, moonless, warm and heavily overcast. The atmosphere threatened rain. Raising the inadequate night-light high, I saw nothing but the chairs we had sat in, empty, the marble-topped table, bare. Then in the gateway to the garden of pines, I spied what at first I took to be a piece of glass, something shining, a broken goblet perhaps. When I brought the light closer, however, I found that it was a slipper with a silver heel and an instep embroidered with leaves and rosebuds. I picked up this slipper (whose mate, incidentally, never did reappear) and put it on the table, then went through the gate into the garden, striking out like a barefoot Diogenes.

Since the gravel was unkind to my feet, I soon abandoned the path I had taken for the grass, wet though it was with heavy dew. I had never been in this part of the grounds before and stayed close to the path, so as not to lose my way. The boughs of the pinetrees that lined it continuously slashed at my face and snatched at my blue dressing gown. I was beginning to be a bit discouraged. The moon came out momentarily, however, just as I reached a kind of clearing where several paths seemed to come together and I was gratified by the sight of Tita's hounds, one the perfect shadow of the other, moving across the glade in a pallid lunar glare. I knew at once I should follow them. 
"Tita! Tita!" I called. There was no answer, but the hounds moved on and I followed after, into the pines again, trusting that they would lead me to her.

Almost immediately, however, I found I had entangled myself in a resiny thicket of boughs, where I was thrashing about, the night-light held high in my hands, when suddenly, utterly to my surprise, something close at the level of my eyes gave a single long-drawn-out agonized shriek. With a beat of wings, a bundle of feathers flew in my face, and I dropped the night-light, which immediately tinkled and went out. And only then did I hear again in my mind, as I hear now, the cries of the peacocks I had heard from beyond the garden wall that afternoon.

Then I was totally lost. It was useless to try to gather up the fragments of my lamp and seemed equally useless to try to find my way back to the Villa in the dark. The sensible thing was to try to find Tita, who would no doubt be able to lead us both.

I called her name at intervals and went after every promising noisebird calls, crackling twigs-stumbling along for what seemed hours, as it gradually dawned on me that I was no longer even in the Villa garden but somewhere in the park, where I had so notably been lost before. A drizzle had begun to fall, penetrating the trees; their dripping foliage soon soaked through the flimsy silk to my skin, wet leaves seeming to gather upon themselves and cluster thicker the further I walked. Other than the rain, the only sounds were the sounds I made myself, the sound of my feet through the grass and ferns, the leaves and branches as I forced a way and they closed with a swish behind me, my own voice, when, pausing only to listen for Tita or her hounds, I shouted her name.

Then, without knowing how it happened, I seemed to find myself in what I knew must be the alley of trees where I had first met her, if only because I felt familiarity in its rounded stones beneath my soles, and had the sense that behind me now in the drizzle loomed the darkened mass of the Count's château. I stopped for a moment to savor this temporary security. And all at once from off to my left came the sound of distant laughter-a laughter that I had known and knew. It was Tita's; and I ran towards her, feeling a hedge tear at my sleeves as I left the alley, plunging through an unseen opening and once more into the trees.

But the laughter was followed only by a fresh burst of loud rainfall in otherwise total silence; and shortly I was as lost as ever in endless brakes. 
Except that the air was unseasonably warm, I would have been very cold. I kept myself alert for the laughter to come again. The rain kept falling now ever more insistently and the woods seemed to have become pitted with murderous dells.

A hundred times, it seemed, I saved myself from a broken neck by barely clutching some luckily jutting root of a shrub or tree; and a hundred times I fell down a slope of trees, bushes, and ferns, only to survive and continue to push miserably onward. The blue dressing gown by this time hung in silken rags. Though almost breathless, I continued to call her name. I began to feel a growing sense of a kind of persecution. Why did she fail to answer my repeated calls? Where had she gone? Why had she run away?

It was in the midst of such thoughts that I fell at last into a dingle so thick that it seemed to have been contrived with a human, and personal, cunning. For several minutes I struggled in vain, merely getting myself more deeply and inescapably entrapped. When at last I got free, the trees had left me completely stripped. And as soon as I was free, almost at once I stumbled and fell, rolling over and over in the darkness down the entire length of a grassy slope.

With the wind knocked out of me I slowly got to my feet. The drizzle had ceased and everything was quiet. The moon came out.

Surrounded by ministering clouds, like a goddess among her handmaids, shining as if it were the sister of the sun, the moon made night as brilliant as mid-day. Within seconds everything around me that had been dark and obscure was made glorious, almost painfully clear.

Before me lay a long narrow sheet of water, a man-made lake or reflecting pool. My feet had come to a halt on its very brink.

To my right it stretched to the steps and slender columns of an exquisite little Palladian pavillion, silvery white against the dark of a clump of pines. To my left it was lost in the moon-cast shadow of a massive dark-faced mountain. And directly in front of me it lay vitreous, argent, glassily smooth, as smooth and revealing as a polished mirror. It was in this mirror that I saw Tita.

She was on her knees, rising slowly from where, in the grass on the other side of the reflecting pool, she had been lying prone, stretching herself to dabble a hand in its silvery water-moon-blanched, dewylimbed, black hair trailing in tendrils over her shoulders and around the gentle nystagmus of her breasts. On either side of her were poised one of the two great hounds, which she patted as she rose to her feet, and 
just behind her, where she now stood, sitting sideways on a long-tailed roan-colored mare, lounged a mat-haired Laet, dark, skinny and dripping, bravely mustached, who laughed as she leaned languidly back and rested one hand on his naked knee. Then they both gazed quietly back into the water together, their eyes following the ripples her fingers had made, which radiated across the pool and broke on the bank at my likewise naked feet. It was not until then that they looked up and saw me.

I shouted her name. They both stared, wordless. I shouted at them again. Then they moved. I saw her shiver, abandoning an attempt to cover her paps and pubis with her hands, looking up at him while using them to wring out and fling back her dripping hair. Through me went a spasm of rage.

In a clap of thunder, clouds came down and covered the moon, the black skies opened and it began to rain in torrents. As a bolt of lightning struck a tree nearby I leapt into the pool. By a second and third bolt I saw them flash-lit, picking up what I suppose were bits of his clothes from the ground, climbing on the horse, and slowly moving into the trees, with the dogs behind them.

Once I had struggled to the other bank, finding the way they had taken into the woods took the better part of an hour. Scratched and torn, I followed as best I could.

Just before dawn as the tops of the mountains were greying into Morgenrot, when the rain had long since ceased, I knocked at the door of a solitary farm-house and I asked for something to eat and drink, and, if possible, some clothes. The head of the household, a buxom widow who measured me with her eye through a narrow slot and who had to put aside a loaded shotgun before she could unbar the door and let me in, was acquainted with the Count and seemed more or less unsurprised at anything that might emanate from the château. While her innumerable children peeped down at me from the loft, she served me some good bread and a bowlful of coffee, which I devoured like a savage. Her husband's trousers fitted me well enough, though the rest of the costume that she produced was almost unreasonably picturesque. I promised handsome payment but she refused in advance, urging me instead to stop and rest. I told her that though I could not stay I would be back, thanked her with genuine gratitude, donned a hat with a black cock's feather in its band, and resumed my pursuit. She stood at the door, wrapped in her shawl, and waved after me as I set off, telling me to take care and not to exhaust myself. 
The chase went on until a little after noon, when it came to an end. On the edge of a meadow, beyond a rough rail fence (where a dead crow, pinned upside down, like some kind of avian homme pendu or grotesquely parodied Saint Peter, was spreading in warning to other crows its cruelly crucified wings) I found the tracks of a single horse. Further on, in an orchard of pear trees, stripping away and eating its fruit, rootless, ruthless, and unrepentant, they had made their last encampment. The ashes of their fires were still quite warm; and deep after heavy rain were the water-filled ruts of their wagon wheels, rolling towards Transylvania. 